or a Lynda Barry - than I am in work created by teams of people, such as we see in genre-driven comics from companies like Marvel and DC. Yet I don't doubt that these teams are doing innovative work, even, and especially, work that plays with or refigures genre conventions-something we also see in work by comics auteurs like Charles Burns, whose brilliant graphic narrative about a teen plague, Black Hole, I mention in my essay (459).

Saunders's letter ends by noting that studying comics today and understanding its adoption as an academic subject for inquiry require skepticism-a notion with which I agree. (Spiegelman's Columbia University course title indicates this too: "Comics: Marching into the Canon" [my emphasis]). I want more, not fewer, informed dialogues about comics to take place, and I look forward to being part of a robust field in which the perspectives of many kinds of critics, with different objects of analysis, have a place. I look forward to reading Saunders's work on comic books and their creative consequences.

Hillary Chute

Harvard University

\section{Imprisonment: Models of Confinement}

\section{To the Editor:}

Avery Gordon has sought a context for understanding the psychological consequences of detainment or containment in "Methodologies of Imprisonment" (123.3 [2008]: 651-57). She asserts four models of confinement, but devotes full attention only to the second:

the United States' model of mass imprisonment of surplus racial and ethnic populations as a form of socioeconomic abandonment; military imprisonment, especially in the course of permanent security wars; the European model of the detention of migrants, asylum seekers, and refugees ("Fortress Europe"); and the Israeli model of occupation by encirclement and immobilization. (651)

Gordon makes her case against the Guantánamo Bay prison, where prisoners of war have been held in disregard of the Geneva Conventions. The presumption of innocence is a major doctrine of the American court system. However, she does not try to instruct the reader about military law regarding the imprisonment of personnel captured in battle. She does not in her argument on behalf of suicides and those frustrated with their incarceration draw distinctions between inmates whose imprisonment at Guantánamo is problematic and those whose terrorist actions might have identified their militancy, led to their capture, and brought them to the prison. Nevertheless, few disagree that Guantánamo should be closed; it has been badly managed, and its existence and operation have serious legal implications.

More egregious is Gordon's assertion that the United States uses its prison system as a means for abandoning socioeconomic classes among racial and ethnic populations, a position neither substantiated nor documented. If concerned with the percentage of minority populations in prison, she has ignored the efforts of criminologists, penologists, and educators trying to fix deep problems. The reasons for incarceration are more complex than Gordon chooses to understand. She ignores problems in education, the job market, or the prisoners' domestic milieu. Indeed, many prisoners in jails read at low levels. Tricia Fox explains that Canadian "prisoners are often lacking in basic skills"; they "demonstrate a high incidence of illiteracy, low intelligence, learning disabilities, and reading disabilities." Their reading levels are measurably inadequate: "the typical inmate functions two or three grade levels below the level completed in school" ("Teaching in Prisons: Consideration of the Concept of Adult Education"; abstract; ERIC ED284070; 1987; Web; 20 Nov. 2008). A report of the National Center on Adult Literacy (NCAL) on American prisons finds that "up to $50 \%$ of adult inmates are functionally illiterate" (Anabel P. Newman, Warren Lewis, and Caroline Beverstock, Prison Literacy: Implications for Program and Assessment Policy [Philadelphia: Natl. Center on Adult Literacy, Clinical Rept. TR9301; Bloomington: ERIC Clearinghouse on Reading and Communication Skills, 1993; B: 18; Web; 
20 Nov. 2008]). They are thus barred from the job market, advanced education, and sustained enterprise. NCAL is a major government agency that has studied the problem and developed learning models in response. It is much too simple for Gordon to argue that it is the nefarious will of the government to incarcerate and mistreat its prisoners and to purposely remove them from society. Gordon's socioeconomic rationalizing looks at the prisons as a mode of abandonment, but she is not prepared to study the depths of the problem (Elizabeth Greenberg, Eric Dunleavy, and Mark Kutner, Literacy behind Bars: Results from the 2003 National Assessment of Adult Literacy Prison Survey [Washington, DC: Natl. Center for Educ. Statistics, 2007; table 5]), which NCAL research addresses at length, offering alternative class options and programs to improve reading and teach job skills.

The most irresponsible of her statements, however, is her likening of prison systems to the manner in which Israel has chosen to defend itself against aggression and fanaticism. She seems unaware of the numbers of wars promulgated against Israel by Arab populations. Israelis have sought to protect their borders with West Bank settlements, some such settlements on disputed, not occupied, land. She ignores the fact, for example, that Israel unilaterally returned Gaza to Palestinian governance only to have the Arabs, themselves, promulgate her European model that detains "migrants, asylum seekers, and refugees." Palestinian Hamas has reduced its citizens to the very "abstract concretization" that Gordon complains about (651). Natan Sharansky and Ron Dermer tell us that a "genuinely 'new' Middle East ... will not be brought about by merely ceding lands to Arab dictators and by subsidizing regimes that undermine the rights of their own people" (The Case for Democracy: The Power of Freedom to Overcome Tyranny and Terror [New York: Perseus, 2004; 189; print]). Ilan Peleg observes the negative "perpetual matrix" that has defined Arab-Jewish relations in Israel and in the occupied territories ("Otherness and Israel's Arab Dilemma"; The Other in Jewish Thought and History; Constructions of Jewish Culture and Identity; ed. Laurence J. Sil- berstein and Robert L. Cohn [New York: New York UP, 1994; 269; print]). In her introductory statement, Gordon does not recognize any of these variances or implications, debated in Israeli society; her argument remains undeveloped and the subject otherwise invisible in her essay, which lays fault on Israel. Hers ought not to be accepted as an ex post facto truth.

Gordon uses the example of suicide attempts by Jumah Abdel-Latif al-Dossari to promote her cause. While we would not wish to diminish the horror of suicides, or minimize al-Dossari's fears and tribulations, suicide at Guantánamo could conceivably prove a means of glorifying one's life through martyrdom. Suicide-like the actions of suicide bombers in Israel-would assure a prisoner a place in the Islamic paradise for conceivable past actions in which American soldiers were killed. While suicide is forbidden in the Koran (4.29), a martyr in jihad ("conflict") will gain heaven (3.169) with its blessing of seventy-two, a number in Hebrew gematriya representing the name of God (E. B. Waite, The Holy Kabbalah: A Study of the Secret Tradition in Israel as Unfolded by Sons of the Doctrine for the Benefit and Consolation of the Elect Dispersed through the Lands and Ages of the Greater Exile; introd. Kenneth Rexroth [1960; Secaucus: University; Citadel, 1967; 16, 618; print]). Gematriya is a system of numerology that assigns numbers to words. Seventy-two has been interpreted by fanatic Muslims as seventy-two virgins, likened to seventy carnal feminine houris providing bliss in paradise (Abdelwahab Bouhdiba, "The Infinite Orgasm"; Sexuality in Islam; trans. Alan Sheridan [London: Routledge, 1985; 75-76; print]), who greet martyrs, a concept not found in the Koran. Al-Dossari's efforts at suicide may not be, as Gordon understands them, a demonstration of his understanding and confirmation of "the enslavement masquerading as freedom the United States has long promoted" (655). Suicidal martyrdom might be fed, as Joel Carmichael suggests, by Marxist models against Jews, cloaked as anti-Zionist, and by Muslim clerics' articulation of the anti-Semitic Protocols of the Elders of Zion, a document officially discredited by Tsar Nicholas II (The Satanizing 
of the Jews: Origin and Development of Mystical Anti-Semitism [New York: Fromm Intl., 1992; 190, 207; print]). Suicides at Guantánamo Bay may have died, similarly, according themselves the role of shahid ("revered holy martyr"), rewarded in consequence of their successful attacks against American soldiers, representatives of the "Great Satan" (David Cook and Olivia Allison, "Self-Sacrifice against the "Great Satan': Al Qa'ida and Martyrdom Operations"; Understanding and Addressing Suicide Attacks: The Faith and Politics of Martyrdom Operations; fwd. Edward P. Djerejian [Westport: Praeger Security Intl., 2007; 48-49; print]). This argument is neither sympathetic nor charitable, but it may not be unrealistic despite that suicide is a forbidden act in the Abrahamic religions. With the shock of suicide bombers in Iraq and elsewhere, Gordon should be empathetic toward and more discursive about the problem that Israelis have been facing for a long time.

$P M L A$ readers expect studied arguments in support of the author's introductory arguments, not polemics.

Irving Rothman

University of Houston

\section{Listening to Sound in Poetry}

\section{To THE EDITOR:}

I was happy to see the double article by Marjorie Perloff and Craig Dworkin, "The Sound of Poetry / The Poetry of Sound" (123.3 [2008]: 749-61), which extended, while it reviewed, the theme of the 2006 MLA convention. For me this was the most interesting and hopeful of a careerful of MLA conventions. It asked attendees to consider a central element of poetry, sound, to put what works too often like an axiom-sound, as Pope said, echoes sense-under the strong light of contention, description, analysis, and discussion. The Presidential Forum and this subsequent double article remind us that sound can act independently from poetic meaning and may make a whole set of assumptions about poetry fall one after the other like dominoes. These assumptions include those that state categorically: a poem equals a lyric; a poem is primarily about the drama of the speaker or lyric subject and consequently "internalizes" the world; and (in one of the basic tenets of the academic and school accounts of poetry) a poem is primarily an act of communication.

The kinds of questioning that the main sessions of this forum encouraged emanated from, among others, poets and artists whose work explicitly questions the givens of poetic form and language. Participants included Susan Howe, Johanna Drucker, Charles Bernstein, and Kenneth Goldsmith. The forum, in other words, examined its topic with the help (predominant though not exclusive) of poets (as opposed to scholar/critics) and experimentalists. Primary attention rested on the poem, often from the perspective of practitioners of the art, so that the intellectual encounter with the subject was most memorably, for me at least, mediated, and thus authenticated, through the writerly.

Toward the end of his essay, Dworkin turns his attention to the venerable linkage between poetry and music, but he unsettles that connection by observing that in the twentieth century "music" itself has changed, no longer meaning "merely euphonious language, a mid-nineteenth-century sense of harmony and melodic line that 'delights the ear" but including twentieth-century workings by the likes of György Ligeti, John Cage, John Zorn, and Iannis Xenakis: "The idea of music in this expanded field ... may be a productive tool for understanding poetry and for thinking in new ways about what poetry might aspire to do" (759). We can take this comment further to our purpose by observing that art on the cutting edge, art that exists in part to test the borders of the too familiar, can itself propose a renewed sense of poetic function and method, often in a language close to the intersection of concept and practice and therefore all the more useful. And as one doesn't, in the twenty-first century, study the physical world through the instrumentalities of Newton, shouldn't we use the most advanced thinking about poetry to best understand it today? We have, in other words, just begun to explore the nature of sound in poetry. 